\title{
Horizons: Foreword
}

Marta Dvorak

\section{(2) OpenEdition}

1 Journals

Electronic version

URL: https://journals.openedition.org/ces/8274

DOI: $10.4000 /$ ces. 8274

ISSN: 2534-6695

\section{Publisher}

SEPC (Société d'études des pays du Commonwealth)

\section{Printed version}

Date of publication: 1 September 2010

Number of pages: 5

ISSN: 2270-0633

\section{Electronic reference}

Marta Dvorak, "Horizons: Foreword", Commonwealth Essays and Studies [Online], 33.1 | 2010, Online since 11 December 2021, connection on 20 January 2022. URL: http://journals.openedition.org/ces/ 8274 ; DOI: https://doi.org/10.4000/ces.8274

\section{(c) (i) (5)}

Commonwealth Essays and Studies is licensed under a Licence Creative Commons Attribution - Pas d'Utilisation Commerciale - Pas de Modification 4.0 International. 


\section{Foreword}

The renowned painting by Turner on our front cover (courtesy The Museum of Fine Arts, Boston) admirably configures the phenomenological, aesthetic, historical, and socio-political issues which this issue's theme, Horizons, addresses. The storm-tossed slaveship in the background and the drowning slaves in the foreground re-present a historical, referential reality which has taken on mythical resonances, calling up to contemporary viewers Derek Walcott's assertion that the sea is history. Rooted in Edmund Burke's sensualist concept of the sublime, the seascape engineers awe and terror in viewers, and articulates the required negotiation between identification (the figures arousing our common dread of death and mortality) and distance (coterminous with the safety of the spectator confronted with a spectacle rather than reality, the inside/outside parameter in turn overlapping with the free/enslaved binary). The horizon and its vanishing point in Turner's seascape transform what certain postcolonial theorists may see as a potentially simplistic figuration of the politically charged and now mythical Middle Passage. The multiple forms of crossing addressed by the painter intersect with a number of this issue's articles, either in a frontal or displaced fashion. The discussions and resulting cross-talk call to mind Edouard Glissant's poetics of relation, in which the foundations of individual and national identityconstruction reside in our relations with the other and the world. The contributors to this issue engage with the questions of subjectivity and perception, rupture and continuation, the monolithic and the multiple, which roil under the surfaces. Turner's representation and the contributors' multifaceted investigations can evoke Kamau Brathwaite's consideration that in the face of the immense diversity of multiform cultures, the unity is submarine.

Marta Dvorak 